\title{
UPAYA MENINGKATKAN PRESTASI BELAJAR IPA DENGAN METODE PEMBELAJARAN PENEMUAN TERBIMBING PADA SISWA KELAS IV SDN 2 SEPONTI
}

\author{
Sarjo \\ SDN 2 Seponti \\ Email: sarjosdn2seponti@gmail.com
}

\begin{abstract}
Abstrak
Berdasarkan pengalaman penulis di lapangan, kegagalan dalam belajar rata-rata dihadapi oleh sejumlah siswa yang tidak memiliki dorongan belajar. Untuk itu dibutuhkan suatu kegiatan yang dilakukan oleh guru dengan upaya membangkitkan motivasi belajar siswa, misalnya dengan membimbing siswa untuk terlibat langsung dalam kegiatan yang melibatkan siswa serta guru yang berperan sebagai pembimbing untuk menemukan konsep IPA. Penelitian ini berdasarkan permasalahan: (a) Bagaimanakah peningkatan prestasi belajar siswa dengan diterapkannya pembelajaran penemuan terbimbing? (b) Bagaimanakah pengaruh metode pembelajaran penemuan terbimbing terhadap motivasi belajar siswa?. Tujuan dari penelitian ini adalah: (a) Ingin mengetahui peningkatan prestasi belajar siswa setelah diterapkannya pembelajaran penemuan terbimbing. (b) Ingin mengetahui pengaruh motivasi belajar siswa setelah diterapkan pembelajaran penemuan terbimbing. Penelitian ini menggunakan penelitian tindakan (action research) sebanyak tiga putaran. Setiap putaran terdiri dari empat tahap yaitu: rancangan, kegiatan dan pengamatan, refleksi, dan refisi. Sasaran penelitian ini adalah siswa Kelas IV SDN 2 Seponti. Data yang diperoleh berupa hasil tes formatif, lembar observasi kegiatan belajar mengajar. Dari hasil analis didapatkan bahwa prestasi belajar siswa mengalami peningkatan dari siklus I sampai siklus III yaitu, siklus I $(65,22 \%)$, siklus II $(78,26 \%)$, siklus III $(91,30 \%)$. Kesimpulan dari penelitian ini adalah metode pembelajaran penemuan terbimbing dapat berpengaruh positif terhadap motivasi belajar Siswa SDN 2 Seponti, serta model pembelajaran ini dapat digunakan sebagai salah satu alternatif pembelajaran IPA.
\end{abstract}

\section{Kata Kunci: Prestasi Belajar IPA, Metode Penemuan Terbimbing}

\section{PENDAHULUAN}

Perkembangan teknologi tidak akan lepas dari perkembangan dalam bidang IPA. Perkembangan dari bidang IPA tidak mungkin terjadi bila tidak disertai dengan peningkatan mutu pendidikan IPA, sedangkan selama ini pelajaran IPA dianggap sebagai pelajaran yang sulit. Hal ini dapat dilihat dari Nilai mata pelajaran IPA yang rata-rata masih rendah bila dibandingkan dengan pelajaran lainnya. Ini Menunjukkan masih rendahnya mutu pelajaran IPA.

Untuk itu diperlukan suatu upaya dalam rangka meningkatkan mutu pendidikan dan pengajaran salah satunya adalah dengan memilih strategi atau cara dalam menyampaikan materi pelajaran agar diperoleh peningkatan prestasi belajar siswa khususnya pelajaran IPA. Misalnya dengan membimbing siswa untuk bersama-sama terlibat aktif dalam proses pembelajaran dan mampu membantu siswa berkembang sesuai dengan taraf intelektualnya akan lebih menguatkan pemahaman siswa terhadap konsep-konsep yang diajarkan. Pemahaman ini memerlukan minat dan motivasi. Tanpa adanya minat menandakan bahwa siswa tidak mempunyai motivasi untuk belajar. Untuk itu, guru harus memberikan suntikan dalam bentuk motivasi sehingga dengan bantuan itu anak didik dapat keluar dari kesulitan belajar.

Berdasarkan pengalaman penulis di lapangan, kegagalan dalam belajar rata-rata dihadapi oleh sejumlah siswa yang tidak memiliki dorongan belajar. Untuk itu dibutuhkan suatu kegiatan yang dilakukan oleh guru dengan upaya membangkitkan motivasi belajar siswa, misalnya 
dengan membimbing siswa untuk terlibat langsung dalam kegiatan yang melibatkan siswa serta guru yang berperan sebagai pembimbing untuk menemukan konsep IPA.

Motivasi tidak hanya menjadikan siswa terlibat dalam kegiatan akademik, motivasi juga penting dalam menentukan seberapa jauh siswa akan belajar dari suatu kegiatan pembelajaran atau seberapa jauh menyerap informasi yang disajikan kepada mereka. Siswa yang termotivasi untuk belajar sesuatu akan menggunakan proses kognitif yang lebih tinggi dalam mempelajari materi itu, sehingga siswa itu akan menyerap dan mengendapan materi itu dengan lebih baik. Tugas penting guru adalah merencanakan bagaimana guru mendukung motivasi siswa (Nur, 2001: 3). Untuk itu sebagai seorang guru disamping menguasai materi, juga diharapkan dapat menetapkan dan melaksanakan penyajian materi yang sesuai kemampuan dan kesiapan anak, sehingga menghasilkan penguasaan materi yang optimal bagi siswa.

Berdasarkan uraian tersebut di atas penulis mencoba menerapkan salah satu model pembelajaran, yaitu metode pembelajaran penemuan terbimbing untuk mengungkapkan apakah dengan metode pembelajaran penemuan terbimbing dapat meningkatkan motivasi belajar dan prestasi belajar IPA. Penulis memilih metode pembelajaran ini mengkondisikan siswa untuk terbiasa menemukan, mencari, mendikusikan sesuatu yang berkaitan dengan pengajaran (Siadari, 2001: 4). Dalam metode pembelajaran penemuan terbimbingn siswa lebih aktif dalam memecahkan untuk menemukan sedang guru berperan sebagai pembimbing atau memberikan petunjuk cara memecahkan masalah itu.

Hal ini sesuai dengan hasil penelitian sebelumnya yang membuktikan bahwa hasil belajar siswa dengan menerapkan metode pembelajaran penemuan terbimbing lebih baik dari hasil belajar siswa yang diajar dengan metode pembelajaran konvensional. (Siadari, 2001:68). Menurut hasil penelitian Arif Kurniawan (2002) menunjukkan bahwa pembelajaran dengan menggunakan metode pembelajaran penemuan terbimbing dapat meningkatkan prestasi belajar siswa, yang ditandai dengan peningkatan prestasi belajar siswa setiap putaran. Serta dengan menggunakan metode pembelajaran penemuan terbimbing terjadi peningkatan pola berpikir kritis dan kreatif pada kelas yang berdampak positif terhadap hasil belajar yang dicapai lebih baik daripada tanpa diberi metode pembelajaran serupa (Lestari, 2002). Dari beberapa hasil penelitian tersebut membuktikan bahwa metode pembelajaran penemuan terbimbing sangat erat digunakan dalam kegiatan pembelajaran terutama kegiatan pembelajaran IPA.

Dari latar belakang di atas maka penulis dalam penelitian ini mengambil judul "Upaya Meningkatkan Prestasi Belajar IPA Dengan Metode Pembelajaran Penemuan Terbimbing Pada Siswa Kelas IV SDN 2 Seponti Tahun Pelajaran 2019/2020".

Sesuai dengan permasalahan di atas, penelitian ini bertujuan untuk: (1) Ingin mengetahui peningkatan prestasi belajar siswa setelah diterapkannya metode pembelajaran penemuan terbimbing pada siswa Kelas IV SDN 2 Seponti tahun pelajaran 2019/2020. (2) Ingin mengetahui pengaruh motivasi belajar siswa setelah diterapkan metode pembelajaran penemuan terbimbing pada siswa Kelas IV SDN 2 Seponti tahun pelajaran 2019/2020. (3)

IPA didefiniksan sebagai suatu kumpulan pengetahuan yang tersusun secara alam. Perkembangan IPA tidak hanya ditandai dengan adanya fakta, tetapi juga oleh adanya metode ilmiah dan sikap ilmiah. Metode ilmiah dan pengamatan ilmiah menekankan pada hakikat IPA.

Secara rinci hakikat IPA menurut Bridgman (dalam Lestari, 2001:7) adalah sebagai berikut: (1) Kualitas; pada dasarnya konsep-konsep IPA selalu dapat dinyatakan dalam bentuk angka-angka. (2) Observasi dan eksperimen; merupakan salah satu cara untuk dapat memahami konsep-konsep IPA secara tepat dan dapat diuji kebenarannya. (3) Ramalan (prediksi); merupakan salah satu asumsi penting dalam IPA bahwa misteri alam raya ini dapat dipahami dan memiliki keteraturan. Dengan asumsi tersebut lewat pengukuran yang teliti maka berbagai peristiwa alam yang akan terjadi dapat diprediksikan secara tepat. (4) Progresif dan komunikatif; artinya IPA itu selalu berkembang ke arah yang lebih sempurna dan penemuanpenemuan yang ada merupakan kelanjutan dari penemuan sebelumnya.

Dari penjelasan di atas, dapat disimpulkan bahwa hakikat IPA, dimana konsep-konsepnya diperoleh melalui suatu proses dengan 
menggunakan metode ilmiah dan diawali dengan sikap ilmiah kemudian diperoleh hasil (produk).

Proses dalam pengertian disini merupakan interaksi semua komponen atau unsur yang terdapat dalam belajar mengajar yang satu sama lainnya saling berhubungan (inter independent) dalam ikatan untuk mencapai tujuan (Usman, 2000:5).

Belajar diartikan sebagai proses perubahan tingkah laku pada diri individu berkat adanya interaksi antara individu dengan lingkungannya. Hal ini sesuai dengan yang diutarakan Burton bahwa seseorang setelah mengalami proses belajar akan mengalami perubahan tingkah laku, baik aspek pengetahuannya, keterampilannya, maupun aspek sikapnya. Misalnya dari tidak bisa menjadi bisa, dari tidak mengerti menjadi mengerti. (dalam Usman, 2000:5).

Mengajar merupakan suatu perbuatan yang memerlukan tanggungjawab moral yang cukup berat. Mengajar pada prinsipnya membimbing siswa dalam kegiatan suatu usaha mengorganisasi lingkungan dalam hubungannya dengan anak didik dan bahan pengajaran yang menimbulkan proses belajar.

Proses belajar mengajar merupakan suatu inti dari proses pendidikan secara keseluruhan dengan guru sebagai pemegangn peran utama. Proses belajar mengajar merupakan suatu proses yang mengandung serangkaian perbuatan guru dan siswa atas dasar hubungan timbal balik yang berlangsung dalam situasi edukatif untuk mencapai tujuan tertentu. Interaksi atau hubungan timbal balik antara guru dan siswa itu merupakan syarat utama bagi berlangsungnya proses belajar mengajar (Usman, 2000:4).

Sedangkan menurut buku Pedoman Guru Pendidikan Agama Islam, proses belajar mengajar dapat mengandung dua pengertian, yaitu rentetan kegiatan perencanaan oleh guru, pelaksanaan kegiatan sampai evaluasi program tindak lanjut (dalam Suryabrata, 1997:18).

Dari kedua pendapat tersebut dapat disimpulkan bahwa proses belajar mengajar IPA meliputi kegiatan yang dilakukan guru mulai dari perencanaan, pelaksanaan kegiatan sampai evaluasi dan program tindak lanjut yang berlangsung dalam situasi edukatif untuk mencapai tujuan tertentu yaitu pengajaran IPA.

Metode pembelajaran penemuan adalah suatu metode pembelajaran dimana dalam proses belajar mengajar guru memperkenankan siswasiswanya menemukan sendiri informasi-informasi yang secara tradisional bisa diberitahukan atau diceramahkan saja (Suryabrata, 1997:1972). Metode pembelajaran ini merupakan suatu cara untuk menyampaikan ide/gagasan melalui proses menemukan. Fungsi pengajar disini bukan untuk menyelesaikan masalah bagi peserta didiknya, melainkan membuat peserta didik mampu menyelesaikan masalah itu sendiri (Hudojo, 1988, 114). Metode pembelajaran yang ekstrim seperti ini sangat sulit dilaksanakan karena peserta didik belum sebagai ilmuwan, tetapi mereka masih calon ilmuwan. Peserta didik masih memerlukan bantuan dari pengajar sedikit demi sedikit sebelum menjadi penemu yang murni. Jadi metode pembelajaran yang mungkin dilaksanakan adalah metode pembelajaran penemuan terbimbing dengan demikian kegiatan belajar mengajar melibatkan secara maksimum baik pengajar maupun pesertra didik.

Seperti uraian di atas bahwa penemuan terbimbing (Guided Discovery) merupakan salah satu dari jenis metode pembelajaran penemuan. Oleh Howe (dalam Hariyono, 2001:3) menyatakan bahwa penemuan terbimbing tidak hanya sekedar keterampilan tangan karena pengalaman, kegiatan pembelajaran dengan model in tidak sepenuhnya diserahkan pada siswa, namum guru masih tetap ambil bagian sebagai pembimbing. Penemuan terbimbing merupakan suatu metode pembelajaran yang tidak langsung (Indirect Instuction). Siswa tetap memiliki porsi besar dalam proses penyelenggaraan kegiatan pembelajaran.

Menurut Soedjadi (dalam Purwaningsari, 2001:1) metode pembelajaran penemuan terbimbing adalah metode pembelajaran yang sengaja dirancang dengan menggunakan pendekatan penemuan. Para siswa diajak atau didorong untuk melakukan kegiatan eksperimental, sedemikian sehingga pada akhirnya siswa dapat menemukan sesuatu yang diharapkan.

Dalam pembelajaran penemuan terbimbing tugas guru cenderung menjadi fasilitator. Tugas ini tidaklah mudah, lebih-lebih kalau menghadapi kelas besar atau siswa yang lambat atau sebaliknya amat cerdas. Karena itu sebelum melaksanakan metode pembelajaran dengan penemuan ini guru perlu benar-benar mempersiapkan diri dengan baik. Baik dalam tiap hal pemahaman konsepkonsep yang akan diajarkan maupun memikirkan 
kemungkinan yang akan terjadi di kelas sewaktu pembelajaran tersebut berjalan. Dengan kata lain guru perlu mempersiapkan pembelajaran dengan cermat, Soedjadi (dalam Purwaningsari, 2001:18).

Keuntungan dan kelemahan metode pembelajaran penemuan terbimbing. (1) Keuntungan metode pembelajaran penemuan terbimbing. (2) Menurut Siadari (2001:26) keuntungan dari pembelajaran metode pembelajaran penemuan terbimbing adalah: (a) Pengetahuan ini dapat bertahan lama, mudah diingat dan mudah diterapkan pada situasi baru. (b) Meningkatkan penalaran, analisis dan keterampilan siswa memecahkan masalaha tanpa pertolongan orang lain. (c) Meningkatkan kreatifitas siswa untuk terus belajar dan tidak hanya menerima saja. (d) Terampil dalam menemukan konsep atau memecahkan masalah.
Kelemahan dalam penemuan konsep atau memecahkan masalah. Adapun kelemahan metode pembelajaran penemuan terbimbing menurut Ruseffendi (dalam Siadari, 2001:26) adalah sebagai berikut: (1) Tidak semua materi dapat disajikan dengan mudah, menggunakan metode pembelajaran penemuan terbimbing. (2) Proses pembelajaran memerlukan waktu yang relatif lebih banyak. (3) Bukan merupakan metode pembelajaran murni, maksudnya tidak dapat berdiri sendiri (hanya dapat digunakan jika ada keterlibatan metode lain misal ekspositori, ceramah, dan lain sebagainya).

Sintak penemuan terbimbing menurut Arends (dalam Haryono, 2001:25), dapat ditabelkan sebagai berikut:

Tabel 1. Sintaks Penemuan Terbimbing Model Arends

\begin{tabular}{cll}
\hline No & \multicolumn{1}{c}{ Fase-fase } & \multicolumn{1}{c}{ Kegiatan Guru } \\
\hline 1 & $\begin{array}{l}\text { Menyampaikan tujuan, } \\
\text { mengelompokkan dan menjelaskan } \\
\text { prosedur discovery }\end{array}$ & $\begin{array}{l}\text { Guru menyampaikan tujuan pembelajaran serta guru } \\
\text { menjelaskan aturan dalam metode pembelajaran } \\
\text { dengan penemuan terbimbing }\end{array}$ \\
\hline 2 & Guru menyampaikan suatu masalah & Guru mejelaskan masalah secara sederhana \\
\hline 3 & Siswa memperoleh data eksperimen & $\begin{array}{l}\text { Guru mengulangi pertanyaan pada siswa tentang } \\
\text { masalah dengan mengarahkan siswa untuk mendapat } \\
\text { informsi yang membantu proses inquiry dan } \\
\text { penemuan }\end{array}$ \\
& & $\begin{array}{l}\text { Guru membantu siswa dlam membuat prediksi dan } \\
\text { mempersiapkan penjelasan masalah }\end{array}$ \\
\hline 4 & $\begin{array}{l}\text { Siswa membuat hipotesis dan } \\
\text { penjelasan }\end{array}$ & $\begin{array}{l}\text { Guru membimbing siswa berfikir tentang proses } \\
\text { intelektual dn proses penemuan dan menghubungkan } \\
\text { dengan pelajaran lain. }\end{array}$ \\
\hline 5 & Analisis proses penemuan &
\end{tabular}

Dari tabel di atas terlihat jelas bahwa guru dalam metode pembelajaran penemuan terbimbing adalah sebagai pembimbing siswa dalam nenemukan konsep.

Motif adalah daya dalam diri seseorang yang mendorongnya untuk melakukan sesuatu, atau keadaan seserang atau organisme yang menyebabkan kesiapan kesiapannya untuk memulai serangkaian tingkah laku atau perbuatan. Sedangkan motivasi adalah suatu proses untuk menggiatkan motif-motif menjadi perbuatan atau tingkah laku untuk memenuhi kebutuhan dan mencapai tujuan, atau keadaan dan kesiapan dalam diri individu yang mendorong tingkah lakunya untuk berbuat sesuatu dalam mencapai tujuan tertentu (Usman, 2000:28).

Sedangkan menurut Djamarah (2002:114) motivasi adalah suatu pendorong yang mengubah energi dalam diri seseorang kedalam bentuk aktivitas nyata untuk mencapai tujuan tertentu. Dalam proses belajar, motivasi sangat diperlukan sebab seseorang yang tidak mempunyai motivasi dalam belajar tidak akan mungkin melakukan aktivitas belajar. Hal ini sesuai dengan yang diungkapkan oleh Nur (2001:3) bahwa siswa yang termotivasi dalam belajar sesuatu akan menggunakan proses kognitif yang lebih tinggi dalam mempelajari materi itu, sehingga siswa itu akan meyerap dan mengendapkan mateti itu 
dengan lebih baik. Jadi motivasi adalah suatu kondisi yang mendorong seseorang untuk berbuat sesuatu dalam mencapai tujuan tertentu.

Motivasi Intrinsik Jenis motivasi ini timbul sebagai akibat dari dalam individu, apakah karena adanya ajakan, suruhan, atau paksaan dari orang lain sehingga dengan kondisi yang demikian akhirnya ia mau melakukan sesuatu atau belajar (Usman, 2000:29). Sedangkan menurut Djamarah (2002:115), motivasi instrinsik adalah motif-motif yang menjadi aktif atau berfungsinya tidak perlu dirangsang dari luar, karena dalam setiap diri individu sudah ada dorongan untuk melakukan sesuatu.

Motivasi Ekstrinsik Jenis motivasi ini timbul sebagai akibat pengaruh dari luar individu, apakah karena adanya ajakan, suruhan, atau paksaan dari orang lain sehingga dengan kondisi yang demikian akhirnya ia mau melakukan sesuatu atau belajar. Misalnya seseorang mau belajar karena ia disuruh oleh orang tuanya agar mendapat peringkat pertama dikelasnya (Usman, 2000:29). Sedangkan menurut Djamarah (2002:117), motivasi ekstrinsik adalah kebalikan dari motivasi intrinsik. Motivasi ekstrinsik adalah motif-motif yang aktif dan berfungsi karena adanya perangsang dari luar.

Dari uraian di atas diketahui bahwa motivsi ekstrinsik adalah motivasi yang timbul dari luar individu yang berfungsinya karena adanya perangsang dari laur, misalnya adanya persaingan, untuk mencapai nilai yang tinggi, dan lain sebagainya.

Belajar dapat membawa suatu perubahan pada individu yang belajar. Perubahan ini merupakan pengalaman tingkah laku dari yang kurang baik menjadi lebih baik. Pengalaman dalam belajar merupakan pengalaman yang dituju pada hasil yang akan dicapai siswa dalam proses belajar di sekolah. Menurut Poerwodarminto (1991:768), prestasi belajar adalah hasil yang dicapai (dilakukan, dekerjakan), dalam hal ini prestasi belajar merupakan hasil pekerjaan, hasil penciptaan oleh seseorang yang diperoleh dengan ketelitian kerja serta perjuangan yang membutuhkan pikiran.

Berdasarkan uraian diatas dapat dikatakan bahwa prestasi belajar yang dicapai oleh siswa dengan melibatkan seluruh potensi yang dimilikinya setelah siswa itu melakukan kegiatan belajar. Pencapaian hasil belajar tersebut dapat diketahui dengan megadakan penilaian tes hasil belajar. Penilaian diadakan untuk mengetahui sejauh mana siswa telah berhasil mengikuti pelajaran yang diberikan oleh guru. Di samping itu guru dapat mengetahui sejauh mana keberhasilan guru dalam proses belajar mengajar di sekolah.

Sejalan dengan prestasi belajar, maka dapat diartikan bahwa prestasi belajar IPA adalah nilai yang diperoleh siswa setelah melibatkan secara langsung/aktif seluruh potensi yang dimilikinya baik aspek kognitif (pengetahuan), afektif (sikap) dan psikomotor (keterampilan) dalam proses belajar mengajar IPA.

Sedangkan metode pembelajaran penemuan terbimbing adalah suatu metode pembelajaran yang memberikan kesempatan dan menuntut siswa terlibat secara aktif di dalam mencapai tujuan pembelajaran dengan memberikan informasi singkat (Siadari, 2001:7). Pengetahuan yang diperoleh dengan belajar penemuan terbimbing akan bertahan lama, mempunyai efek transfer yang lebih baik dan meningkatkan siswa dan kemampuan berfikir secara bebas. Secara umum belajar penemuan terbimbing ini melatih keterampilan kognitif untuk menemukan dan memecahkan masalah tanpa pertolongan orang lain. Selain itu, belajar penemuan membangkitkan keingintahuan siswa, memberi motivasi untuk bekerja sampai menemukan jawaban (Syafi'udin, 2002:19).

Dari uraian tersebut di atas dapat disimpulkan bahwa dengan adanya motivasi dalam pembelajaran metode pembelajaran penemuan terbimbing tersebut maka hasil-hasil belajar akan menjadi optimal. Makin tepat motivasi yang diberikan, akan makin berhasil pula pelajaran itu. Dengan motivasi yang tinggi maka intensitas usaha belajar siswa akan tingi pula. Jadi motivasi akan senantiasa menentukan intesitas usaha belajar siswa. Hasil ini akan dapat meningkatkan prestasi belajar siswa.

\section{METODE PENELITIAN}

Sesuai dengan jenis penelitian yang dipilih, yaitu penelitian tindakan, maka penelitian ini menggunakan model penelitian tindakan dari Kemmis dan Taggart (dalam Arikunto, 2002: 83), yaitu berbentuk spiral dari siklus yang satu ke siklus yang berikutnya. Setiap siklus meliputi planning (rencana), action (tindakan), observation (pengamatan), dan reflection (refleksi). Langkah pada siklus berikutnya adalah perncanaan yang 
sudah direfisi, tindakan, pengamatan, dan refleksi. Sebelum masuk pada siklus 1 dilakukan tindakan pendahuluan yang berupa identifikasi permasalahan.

Tempat penelitian adalah tempat yang digunakan dalam melakukan penelitian untuk memperoleh data yang diinginkan. Penelitian ini bertempat di SDN 2 Seponti tahun pelajaran 2019/2020.

Waktu penelitian adalah waktu berlangsungnya penelitian atau saat penelitian ini dilangsungkan. Penelitian ini dilaksanakan pada bulan Agustus sampai dengan bulan November semester ganjil 2019/2020.

Subyek penelitian adalah siswa-siswi Kelas IV SDN 2 Seponti tahun pelajaran 2019/2020 pokok bahasan bagian-bagian tumbuhan.

Prosedur pelaksanaan penelitian tindakan Kelas ini terdiri dari tiga siklus. Masing-masing siklus dilaksanakan sesuai dengan perubahan yang dicapai, seperti yang telah didesain dalam faktorfaktor yang diselidiki. Untuk mengetahui permasalahan efektivitas pembelajaran ilmu pengetahuan alam di SDN 2 Seponti dilakukan observasi terhadap kegiatan pembelajaran yang dilakukan guru selain itu diadakan diskusi antara guru sebagai peneliti dengan para pengamat sebagai kolaborator dalam penelitian ini. Melalui langkah-langkah tersebut akan diapat ditentukan bersama-sama antara guru dan pengamat untuk menetapkan tindakan yang tepat dalam rangka meningkatkan efektivitas pembelajaran ilmu pengetahuan alam.

Berdasarkan hasil diskusi dengan para kolabotor, maka langkah yang paling tepat untuk meningkatkan pembelajaran adalah dengan meningkatkan motivasi, aktivitas dan peran serta siswa dalam kegiatan pembelajaran tersebut. Sehubungan dengan hal tersebut, maka tindakan yang paling tepat adalah dengan mengembangkan keterampilan intelektual siswa.

Dengan berpedoman pada refleksi awal tersebut, maka prosedur pelaksanaan penelitian tindakan kelas ini meliputi: (1) perencanaan, (2) pelaksanaan tindakan, (3) observasi, dan (4) refleksi dalam setiap siklus.

Secara rinci prosedur penelitian tindakan ini dijabarban dalam uraian berikut ini. (1) Tahap Perencanaan Pada tahap perencanaan ini kegiatannya meliputi: (a) Peneliti dan pengamat menetapkan alternatif peningkatan efektivitas pembelajaran ilmu pengetahuan alam. (b) Peneliti bersama-sama kolaborator membuat perencanaan pengajaran yang mengembangkan keterampilan intelektual. (c) Mendiskusikan tentang pembelajaran ilmu pengetahuan alam yang mengembangkan keterampilan intelektual siswa. (D) Menginventarisir media pembelajaran. (e) Membuat lembar observasi. (f) Mendesain alat evaluasi

Tahap Pelaksanaan Tindakan Pada tahap pelaksanaan tindakan ini kegiatanyaan adalah melaksanakan kegiatan pembelajaran sebagaimana yang telah direncanakan.

Tahap Observasi Pada tahap observasi ini kegiatan yang dilaksanakan yaitu mengobservasi terhadap pelaksanaan tindakan dengan menggunakan lembar observasi yang telah dipersiapkan.

Tahap Refleksi Pada tahap refleksi ini kegiatannya yaitu meliputi analisis data yang diperoleh melalui observasi pengamatan. Berdasarkan hasil observasi tersebut, guru dapat merefleksikan diri tentang kegiatan pembelajaran yang telah dilakukan. Dengan demikian, guru akan dapat mengetahui efektivitas kegiatan pembelajaran yang telah dilakukan. Berdasarkan hasil refleksi ini akan dapat diketahui kelemahan kegiatan pembelajaran yang dilakukan oleh guru sehingga dapat digunakan untuk menentukan tindakan pada siklus selanjutnya.

Instrumen yang digunakan dalam penelitian ini terdiri dari: (1) Rencana Pelajaran (RP) Yaitu merupakan perangkat pembelajaran yang digunakan sebagai pedoman guru dalam mengajar dan disusun untuk tiap putaran. Masing-masing RP berisi kompetensi dasar, indikator pencapaian hasil belajar, tujuan pembelajaran khusus, dan kegiatan belajar mengajar. (2) Lembar Observasi Kegiatan Belajar Mengajar. Lembar observasi pengelolaan metode pembelajaran kooperatif, untuk mengamati kemampuan guru dalam mengelola pembelajaran. (3) Lembar observasi aktivitas siswa dan guru, untuk mengamati aktivitas siswa dan guru selama proses pembelajaran. (4) Tes formatif Tes ini disusun berdasarkan tujuan pembelajaran yang akan dicapai, digunakan untuk mengukur kemampuan pemahaman konsep ilmu pengetahuan alam pada pokok bahasan operasi hitung pecahan. Tes formatif ini diberikan setiap akhir putaran. Bentuk 
soal yang diberikan adalah pilihan ganda (objektif).

Untuk mengetahui keefektivan suatu metode dalam kegiatan pembelajaran perlu diadakan analisa data. Pada penelitian ini menggunakan teknik analisis deskriptif kualitatif, yaitu suatu metode penelitian yang bersifat menggambarkan kenyataan atau fakta sesuai dengan data yang diperoleh dengan tujuan untuk mengetahui prestasi belajar yang dicapai siswa juga untuk memperoleh respon siswa terhadap kegiatan pembelajaran serta aktivitas siswa selama proses pembelajaran.

\section{HASIL DAN PEMBAHASAN PENELITIAN Analisis Data Penelitian Persiklus Siklus I}

Tahap Perencanaan Pada tahap ini peneliti mempersiapkan perangkat pembelajaran yang terdiri dari rencana pelajaran 1 , LKS 1 , soal tes formatif 1, dan alat-alat pengajaran yang mendukung.

Tahap Kegiatan dan Pelaksanaan Pelaksanaan kegiatan belajar mengajar untuk siklus I dilaksanakan pada tanggal 5 September 2019 di Kelas IV dengan jumlah siswa 23 siswa. Dalam hal ini peneliti bertindak sebagai guru. Adapun proses belajar mengajar mengacu pada rencana pelajaran yang telah dipersiapkan. Pengamatan (observasi) dilaksanakan bersamaan dengan pelaksaaan belajar mengajar.

Pada akhir proses belajar mengajar siswa diberi tes formatif I dengan tujuan untuk mengetahui tingkat keberhasilan siswa dalam proses belajar mengajar yang telah dilakukan. Adapun data hasil penelitian pada siklus I adalah sebagai berikut:

Tabel 2. Pengelolan Pembelajaran Pada Siklus I

\begin{tabular}{|c|c|c|c|c|}
\hline \multirow{2}{*}{ No } & \multirow{2}{*}{ Aspek yang diamati } & \multicolumn{2}{|c|}{ Penilaian } & \multirow[t]{2}{*}{ Rata-rata } \\
\hline & & P1 & $\mathbf{P 2}$ & \\
\hline & \multicolumn{4}{|l|}{ Pengamatan KBM } \\
\hline & \multicolumn{4}{|l|}{ A. Pendahuluan } \\
\hline & 1. Memotivasi siswa & 3 & 2 & 2,5 \\
\hline & 2. Menyampaikan tujuan pembelajaran & 1 & 2 & 1,5 \\
\hline & B. Kegiatan Inti & & & \\
\hline & 1. Mendiskusikan & 3 & 3 & 3 \\
\hline & bersama siswa & 3 & 3 & 3 \\
\hline & 2. Membimbing siswa melakukan kegiatan & & & \\
\hline \multirow[t]{6}{*}{ I } & $\begin{array}{l}\text { 3. Membimbing siswa mendiskusikan hasil kegiatan } \\
\text { dalam kelompok }\end{array}$ & 3 & 3 & 3 \\
\hline & $\begin{array}{l}\text { 4. Memberikan kesempatan pada siswa untuk } \\
\text { mempresentasikan hasil kegiatan belajar mengajar }\end{array}$ & 3 & 3 & 3 \\
\hline & $\begin{array}{l}\text { 5. Membimbing siswa merumuskan } \\
\text { kesimpulan/menemukan konsep }\end{array}$ & 3 & 3 & 3 \\
\hline & C. Penutup & & & \\
\hline & 1. Membimbing siswa membuat rangkuman & 3 & 3 & 3 \\
\hline & 2. Memberikan evaluasi & 3 & 3 & 3 \\
\hline \multirow[t]{2}{*}{ II } & Pengelolaan Waktu & 2 & 2 & 2 \\
\hline & Antusiasme Kelas & & & \\
\hline \multirow[t]{3}{*}{ III } & 1. Siswa Antusias & 3 & 3 & 3 \\
\hline & 2. Guru Antusias & 3 & 3 & 3 \\
\hline & Jumlah & 31 & 31 & 31 \\
\hline \multicolumn{5}{|c|}{ Keterangan: Nilai $\quad$ : Kriteria } \\
\hline & $1 . \quad$ : Tidak Baik & & & \\
\hline & : Kurang Baik & & & \\
\hline & Cukup Baik & & & \\
\hline & : Baik & & & \\
\hline
\end{tabular}


Berdasarkan tabel di atas aspek-aspek yang mendapatkan kriteria kurang baik adalah memotivasi siswa, menyampaikan tujuan pembelajaran, pengelolaan waktu. Ketiga aspek yang mendapat penilaian kurang baik di atas, merupakan suatu kelemahan yang terjadi pada siklus I. Dan akan dijadikan bahan kajian untuk refleksi dan revisi yang akan dilakukan pada siklus II. Hasil observasi berikutnya adalah aktivitas guru dan siswa seperti pada tabel berikut.

Tabel 3. Aktivitas Guru dan Siswa Pada Siklus I

\begin{tabular}{clc}
\hline No & \multicolumn{1}{c}{ Aktivitas Guru yang Diamati } & Persentase \\
\hline 1 & Menyampaikan tujuan & 10.00 \\
2 & Memotivasi siswa/merumuskan masalah & 10.00 \\
3 & Mengkaitkan dengan pelajaran berikutnya & 6.67 \\
4 & Menyampaikan materi/langkah-langkah/strategi & 8.33 \\
5 & Menjelaskan materi yang sulit & 13.33 \\
6 & Membimbing dan mengamati siswa dalam menemukan konsep & 15.00 \\
7 & Meminta siswa menyajikan dan mendiskusikan hasil kegiatan & 10.00 \\
8 & Memberikan umpan balik & 18.33 \\
9 & Membimbing siswa merangkum pelajaran & 8.33 \\
\hline No & $\quad$ Aktivitas Siswa yang diamati & Persentase \\
\hline 1 & Mendengarkan/memperhatikan penjelasan guru & 19.16 \\
2 & Membaca buku siswa & 11.86 \\
3 & Bekerja dengan sesama anggota kelompok & 18.13 \\
4 & Diskusi antar siswa/antara siswa dengan guru & 14.38 \\
5 & Menyajikan hasil pembelajaran & 5.83 \\
6 & Mengajukan/menanggapi pertanyaan/ide & 5.63 \\
7 & Menulis yang relevan dengan KBM & 9.17 \\
8 & Merangkum pembelajaran & 6.86 \\
9 & Mengerjakan tes evaluasi & 8.96 \\
\hline
\end{tabular}

Berdasarkan tabel di atas tampak bahwa aktivitas guru yang paling dominan pada siklus I adalah memberi umpan balik dan membimbing dan mengamati siswa dalam menemukan konsep yaitu masing-masing 18,33 dan 15,00\%. Aktivitas lain yang persentasenya cukup besar adalah menjelaskan materi yang sulit dan menjelaskan materi yang sulit yaitu $13,33 \%$. Sedangkan aktivitas siswa yang paling dominan adalah mengerjakan/memperhatikan penjelasan guru yaitu $19,16 \%$. Aktivitas lain yang persentasenya cukup besar adalah bekerja dengan sesama anggota kelompok, diskusi antar siswa/antara siswa dengan guru, dan membaca buku yaitu masing-masing $18,13 \%, 14,38$ dan $11,86 \%$.

Pada siklus I, secara garis besar kegiatan belajar mengajar dengan metode penemuan terbimbing sudah dilaksanakan dengan baik, walaupun peran guru masih cukup dominan untuk memberikan penjelasan dan arahan karena model tersebut masih dirasakan baru oleh siswa. Berikutnya adalah rekapitulasi hasil tes formatif siswa seperti terlihat pada tabel berikut.

Tabel 4. Rekapitulasi Hasil Tes Siklus I

\begin{tabular}{clc}
\hline No & \multicolumn{1}{c}{ Uraian } & Hasil Siklus I \\
\hline 1 & Jumlah siswa yang tuntas & 15 \\
2 & Jumlah siswa belum tuntas & 8 \\
3 & Nilai rata-rata tes formatif & 67,82 \\
4 & Persentase ketuntasan belajar & 65,22 \\
\hline
\end{tabular}


Dari tabel di atas dapat dijelaskan bahwa dengan menerapkan metode pembelajaran penemuan terbimbing diperoleh nilai rata-rata prestasi belajar siswa adalah 67,82 dan ketuntasan belajar mencapai $65,22 \%$ atau ada 15 siswa dari 23 siswa sudah tuntas belajar. Hasil tersebut menunjukkan bahwa pada siklus pertama secara klasikal siswa belum tuntas belajar, karena siswa yang memperoleh nilai $\geq 65$ hanya sebesar $65,22 \%$ lebih kecil dari persentase ketuntasan yang dikehendaki yaitu sebesar $85 \%$. Hal ini disebabkan karena siswa masih merasa baru dan belum mengerti apa yang dimaksudkan dan digunakan guru dengan menerapkan metode pembelajaran penemuan terbimbing.

Siklus II

Tahap perencanaan Pada tahap ini peneliti mempersiapkan perangkat pembelajaran yang terdiri dari rencana pelajaran 2 , LKS 2 , soal tes formatif II, dan alat-alat pengajaran yang mendukung.

Tahap kegiatan dan pelaksanaan Pelaksanaan kegiatan belajar mengajar untuk siklus II dilaksanakan pada tanggal 12 Oktober 2019 di Kelas IV dengan jumlah siswa 23 siswa. Dalam hal ini peneliti bertindak sebagai guru. Adapun proses belajar mengajar mengacu pada rencana pelajaran dengan memperhatikan revisi pada siklus I, sehingga kesalahan atau kekurangan pada siklus I tidak terulang lagi pada siklus II. Pengamatan (observasi) dilaksanakan bersamaan dengan pelaksanaan belajar mengajar.

Pada akhir proses belajar mengajar siswa diberi tes formatif II dengan tujuan untuk mengetahui tingkat keberhasilan siswa selama proses belajar mengajar yang telah dilakukan. Instrumen yang digunakan adalah tes formatif II. Adapun data hasil penelitian pada siklus II adalah sebagai berikut.

Tabel 5. Pengelolaan Pembelajaran Pada Siklus II

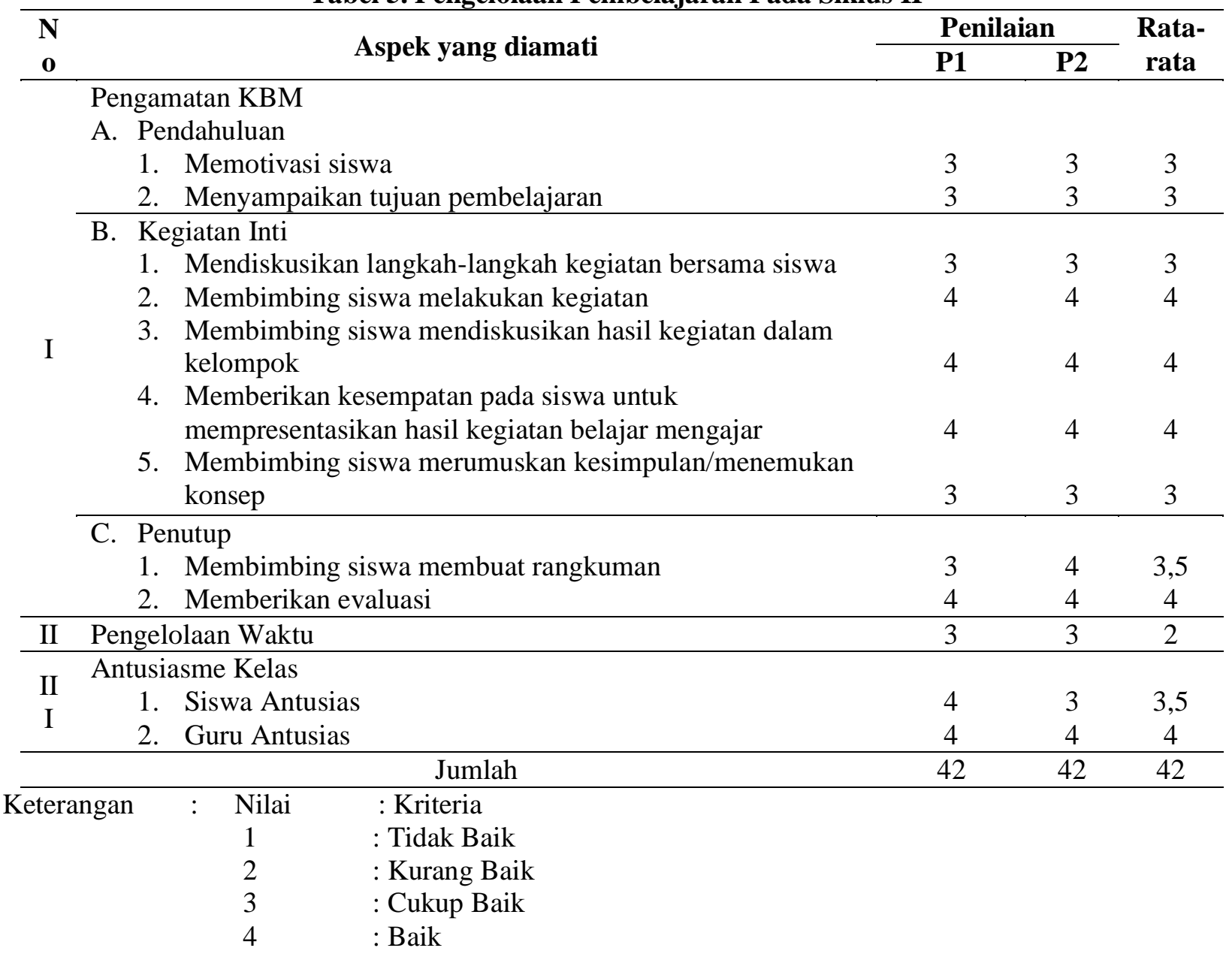


Dari tabel diatas, tampak aspek-aspek yang diamati pada kegiatan belajar mengajar (siklus II) yang dilaksanakan oleh guru dengan menerapkan strategi pembelajaran peningkatan kemampuan berpikir mendapatkan penilaian yang cukup baik dari pengamat. Maksudnya dari seluruh penilaian tidak terdapat nilai kurang. Namum demikian penilaian tersebut belum merupakan hasil yang optimal, untuk itu ada beberapa aspek yang perlu mendapatkan perhatian untuk penyempurnaan penerapan pembelajaran selanjutnya. Aspek-aspek tersebut adalah memotivasi siswa, membimbing siswa merumuskan kesimpulan/ menemukan konsep, dan pengelolaan waktu.

Dengan penyempurnaan aspek-aspek di atas dalam penerapan strategi pembelajaran peningkatan kemampuan berpikir diharapkan siswa dapat menyimpulkan apa yang telah mereka pelajari dan mengemukakan pendapatnya sehingga mereka akan lebih memahami tentang apa yang telah mereka lakukan.

Berikut disajikan hasil observasi aktivitas guru dan siswa:

Tabel 6. Aktivitas Guru Dan Siswa Pada Siklus II

\begin{tabular}{clc}
\hline No & \multicolumn{1}{c}{ Aktivitas Guru yang diamati } & Persentase \\
\hline 1 & Menyampaikan tujuan & 3,33 \\
2 & Memotivasi siswa/merumuskan masalah & 10,00 \\
3 & Mengkaitkan dengan pelajaran berikutnya & 6,67 \\
4 & Menyampaikan materi/langkah-langkah/strategi & 11,67 \\
5 & Menjelaskan materi yang sulit & 18,33 \\
6 & Membimbing dan mengamati siswa dalam menentukan konsep & 15,00 \\
7 & Meminta siswa menyajikan dan mendiskusikan hasil kegiatan & 8,33 \\
8 & Memberikan umpan balik & 18,33 \\
9 & Membimbing siswa merangkum pelajaran & 8,33 \\
\hline No & $\quad$ Aktivitas Siswa yang diamati & Persentase \\
\hline 1 & Mendengarkan/memperhatikan penjelasan guru & 18,12 \\
2 & Membaca buku siswa & 15,63 \\
3 & Bekerja dengan sesama anggota kelompok & 20,21 \\
4 & Diskusi antar siswa/antara siswa dengan guru & 14,76 \\
5 & Menyajikanhasil pembelajaran & 3,33 \\
6 & Mengajukan/menanggapi pertanyaan/ide & 6,67 \\
7 & Menulis yang relevan dengan KBM & 7,91 \\
8 & Merangkum pembelajaran & 6,67 \\
9 & Mengerjakan tes evaluasi/latihan & 6,67 \\
\hline
\end{tabular}

Berdasarkan tabel di atas tampak bahwa aktivitas guru yang paling dominan pada siklus II adalah menjelaskan materi yang sulit dan memberikan umpan balik yaitu masing-masing $18,33 \%$, kemudian menyampaikan langkahlangkah strategis yaitu $11,67 \%$. Sedangkan untuk aktivitas siswa yang paling dominan pada siklus II adalah Bekerja dengan sesama anggota kelompok, mendengarkan penjelasan guru, membaca buku, dan diskusi antar siswa/antara siswa dengan guru yaitu $20,21 \%, 18,12 \%, 15,63 \%$ dan $14,76 \%$.

Berikutnya adalah rekapitulasi hasil tes formatif siswa terlihat pada tabel berikut

Tabel 7. Rekapitulasi Hasil Tes Siklus II

\begin{tabular}{ccc}
\hline No & Uraian & Hasil Siklus II \\
\hline 1 & Jumlah siswa yang tuntas & 18 \\
2 & Jumlah siswa belum tuntas & 5 \\
3 & Nilai rata-rata tes formatif & 73,48 \\
4 & Persentase ketuntasan belajar & 78,26 \\
\hline
\end{tabular}


Dari tabel di atas diperoleh nilai rata-rata prestasi belajar siswa adalah 73,48 dan ketuntasan belajar mencapai $78,26 \%$ atau ada 18 siswa dari 23 siswa sudah tuntas belajar. Hasil ini menunjukkan bahwa pada siklus II ini ketuntasan belajar secara klasikal telah mengalami peningkatan sedikit lebih baik dari siklus I. Adanya peningkatan hasil belajar siswa ini karena setelah guru menginformasikan bahwa setiap akhir pelajaran akan selalu diadakan tes sehingga pada pertemuan berikutnya siswa lebih termotivasi untuk belajar.

Siklus III

Tahap Perencanaan Pada tahap ini peneliti mempersiapkan perangkat pembelajaran yang terdiri dari rencana pelajaran 3 , LKS 3 , soal tes formatif 3 , dan alat-alat pengajaran yang mendukung.
Tahap kegiatan dan pengamatan Pelaksanaan kegiatan belajar mengajar untuk siklus III dilaksanakan pada tanggal 1 November 2019 di Kelas IV dengan jumlah siswa 23 siswa. Adapun proses belajar mengajar mengacu pada rencana pelajaran dengan memperhatikan revisi pada siklus II, sehingga kesalahan atau kekurangan pada siklus II tidak terulang lagi pada siklus III. Pengamatan (observasi) dilaksanakan bersamaan dengan pelaksanaan belajar mengajar. Pada akhir proses belajar mengajar siswa diberi tes formatif III dengan tujuan untuk mengetahui tingkat keberhasilan siswa dalam proses belajar mengajar yang telah dilakukan. Instrumen yang digunakan adalah tes formatif III. Adapun data hasil penelitian pada siklus III adalah sebagai berikut:

Tabel 8. Pengelolaan Pembelajaran Pada Siklus II

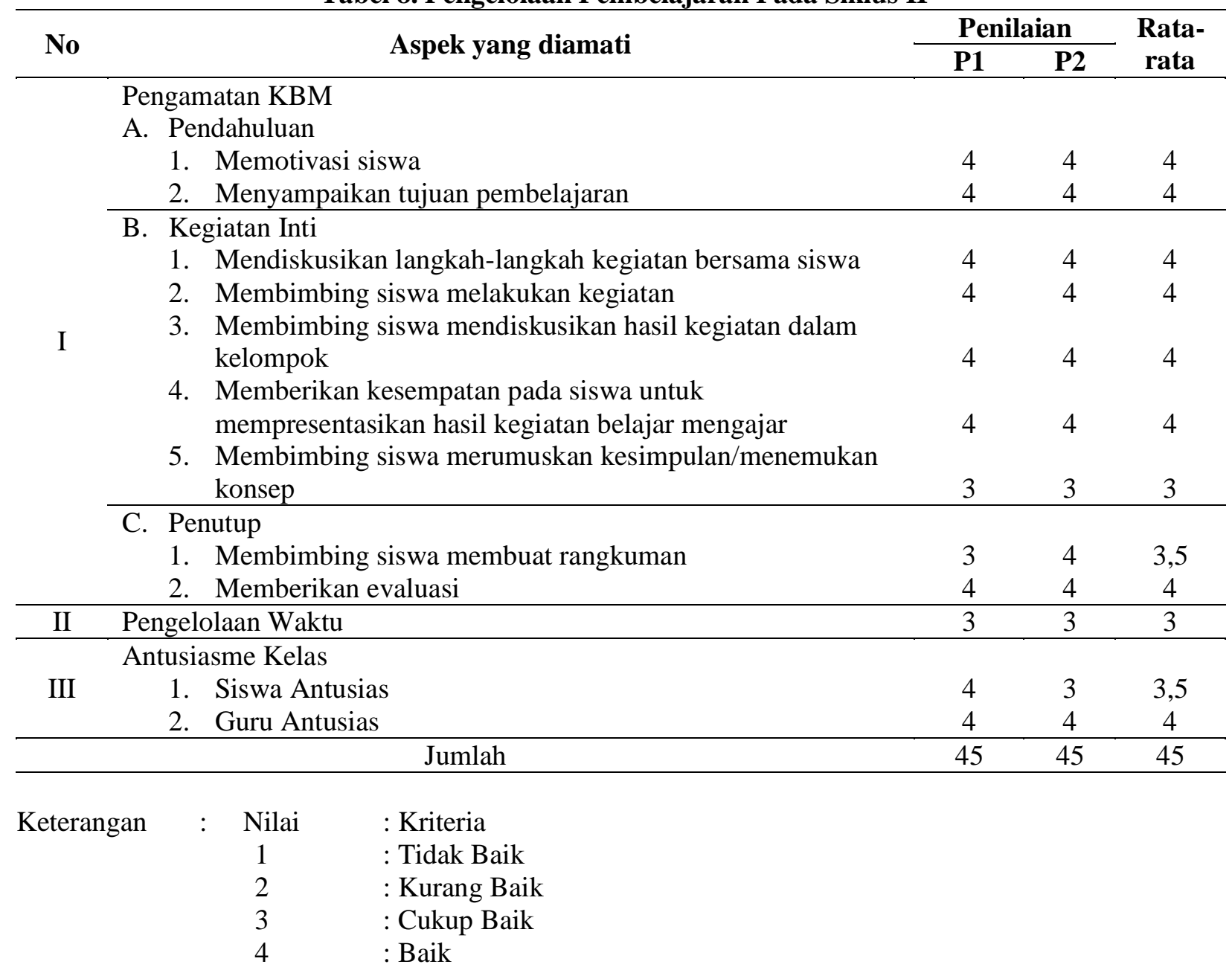


Dari tabel di atas, dapat dilihat aspek-aspek yang diamati pada kegiatan belajar mengajar (siklus II) yang dilaksanakan oleh guru dengan menerapkan metode penemuan terbimbing mendapatkan penilaian cukup baik dari pengamat adalah memotivasi siswa, membimbing siswa merumuskan kesimpulan/menemukan konsep, dan pengelolaan waktu.

Penyempurnaan aspek-aspek diatas dalam menerapkan metode penemuan terbimbing diharapkan dapat berhasil semaksimal mungkin.

Berikut disajikan hasil observasi aktivitas guru dan siswa.

Tabel 9. Aktivitas Guru Dan Siswa Pada Siklus II

\begin{tabular}{clc}
\hline No & \multicolumn{1}{c}{ Aktivitas Guru yang diamati } & Persentase \\
\hline 1 & Menyampaikan tujuan & 8.33 \\
2 & Memotivasi siswa/merumuskan masalah & 10.00 \\
3 & Mengkaitkan dengan pelajaran berikutnya & 6.67 \\
4 & Menyampaikan materi/langkah-langkah/strategi & 13.33 \\
5 & Menjelaskan materi yang sulit & 11.67 \\
6 & Membimbing dan mengamati siswa dalam menentukan konsep & 15.00 \\
7 & Meminta siswa menyajikan dan mendiskusikan hasil kegiatan & 8.33 \\
8 & Memberikan umpan balik & 16.67 \\
9 & Membimbing siswa merangkum pelajaran & 10.00 \\
\hline No & $\quad$ Aktivitas Siswa yang diamati & Persentase \\
\hline 1 & Mendengarkan/memperhatikan penjelasan guru & 9.38 \\
2 & Membaca buku siswa & 8.96 \\
3 & Bekerja dengan sesama anggota kelompok & 11.67 \\
4 & Diskusi antar siswa/antara siswa dengan guru & 11.46 \\
5 & Menyajikan hasil pembelajaran & 12.08 \\
6 & Mengajukan/menanggapi pertanyaan/ide & 10.63 \\
7 & Menulis yang relevan dengan KBM & 14.57 \\
8 & Merangkum pembelajaran & 12.29 \\
9 & Mengerjakan tes evaluasi/latihan & 8.96 \\
\hline
\end{tabular}

Berdasarkan tabel di atas tampak bahwa aktivitas guru yang paling dominan pada siklus II adalah memberi umpan balik yaitu $16,67 \%$, membimbing dan mengamati siswa dalam menemukan konsep yaitu $15.00 \%$. Jika dibandingkan dengan siklus I, aktivitas ini mengalami penurunan. Aktivitas guru yang mengalami peningkatan adalah menyampaikan materi/langkah-langkah/strategi dan memberi umpan balik/evaluasi/tanya jawab yaitu $13.33 \%$ dan $16,67 \%$.

Sedangkan untuk aktivitas siswa yang paling dominan pada siklus II adalah menulis yang relevan dengan $\mathrm{KBM}$ yaitu $14,57 \%$, merangkum pembelajaran $12,29 \%$ dan menyajikan hasil pembelajaran yaitu $(12,08 \%)$.

Berikutnya adalah rekapitulasi hasil tes formatif siswa seperti terlihat pada tabel berikut

Tabel 10. Rekapitulasi Hasil Tes Siklus III

\begin{tabular}{ccc}
\hline No & Uraian & Hasil Siklus III \\
\hline 1 & Jumlah siswa yang tuntas & 21 \\
2 & Jumlah siswa belum tuntas & 2 \\
3 & Nilai rata-rata tes formatif & 77,39 \\
5 & Persentase ketuntasan belajar & 91,30 \\
\hline
\end{tabular}

Berdasarkan tabel diatas diperoleh nilai ratarata tes formatif sebesar 77,39 dan dari 23 siswa yang telah tuntas sebanyak 21 siswa dan 2 siswa belum mencapai ketuntasan belajar. Maka secara 
klasikal ketuntasan belajar yang telah tercapai sebesar 91,30\% (termasuk kategori tuntas). Hasil pada siklus III ini mengalami peningkatan lebih baik dari siklus II. Adanya peningkatan hasil belajar pada siklus III ini dipengaruhi oleh adanya peningkatan kemampuan guru dalam menerapkan pembelajaran penemuan terbimbing sehingga siswa menjadi lebih terbiasa dengan pembelajaran seperti ini sehingga siswa lebih mudah dalam memahami materi yang telah diberikan.

Pada tahap ini akah dikaji apa yang telah terlaksana dengan baik maupun yang masih kurang baik dalam proses belajar mengajar dengan penerapan pembelajaran penemuan terbimbing. Dari data-data yang telah diperoleh dapat diuraikan sebagai berikut: (1) Selama proses belajar mengajar guru telah melaksanakan semua pembelajaran dengan baik. Meskipun ada beberapa aspek yang belum sempurna, tetapi persentase pelaksanaannya untuk masing-masing aspek cukup besar. (2) Berdasarkan data hasil pengamatan diketahui bahwa siswa aktif selama proses belajar berlangsung. (3) Kekurangan pada siklus-siklus sebelumnya sudah mengalami perbaikan dan peningkatan sehingga menjadi lebih baik. (4) Hasil belajar siswa pada siklus III mencapai ketuntasan.

Pada siklus III guru telah menerapkan pembelajaran penemuan terbimbing dengan baik dan dilihat dari aktivitas siswa serta hasil belajar siswa pelaksanaan proses belajar mengajar sudah berjalan dengan baik. Maka tidak diperlukan revisi terlalu banyak, tetapi yang perlu diperhatikan untuk tindakan selanjutnya adalah memaksimalkan dan mempertahankan apa yang telah ada dengan tujuan agar pada pelaksanaan proses belajar mengajar selanjutnya penerapan pembelajaran penemuan terbimbing dapat meningkatkan proses belajar mengajar sehingga tujuan pembelajaran dapat tercapai.

Pembahasan

Melalui hasil peneilitian ini menunjukkan bahwa pembelajaran penemuan terbimbing memiliki dampak positif dalam meningkatkan prestasi belajar siswa. Hal ini dapat dilihat dari semakin mantapnya pemahaman siswa terhadap materi yang disampaikan guru (ketuntasan belajar meningkat dari sklus I, II, dan II) yaitu masingmasing $65,22 \%, 78,26 \%$, dan $91,30 \%$. Pada siklus III ketuntasan belajar siswa secara klasikal telah tercapai.
Berdasarkan analisis data, diperoleh aktivitas siswa dalam proses pembelajaran penemuan terbimbing dalam setiap siklus mengalami peningkatan. Hal ini berdampak positif terhadap prestasi belajar siswa yaitu dapat ditunjukkan dengan meningkatnya nilai rata-rata siswa pada setiap siklus yang terus mengalami peningkatan.

Berdasarkan analisis data, diperoleh aktivitas siswa dalam proses pembelajaran IPA pada pokok bahasan bagian-bagian tumbuhan dengan metode pembelajaran penemuan terbimbing yang paling dominan adalah bekerja dengan menggunakan alat/media, mendengarkan/ memperhatikan penjelasan guru, dan diskusi antar siswa/antara siswa dengan guru. Jadi dapat dikatakan bahwa aktivitas siswa dapat dikategorikan aktif.

Sedangkan untuk aktivitas guru selama pembelajaran telah melaksanakan langah-langkah pembelajaran penemuan terbimbing dengan baik. Hal ini terlihat dari aktivitas guru yang muncul di antaranya aktivitas membimbing dan mengamati siswa dalam mengerjakan kegiatan LKS/menemukan konsep, menjelaskan/melatih menggunakan alat, memberi umpan balik/evaluasi/tanya jawab dimana prosentase untuk aktivitas di atas cukup besar.

\section{SIMPULAN DAN SARAN Simpulan}

Dari hasil kegiatan pembelajaran yang telah dilakukan selama tiga siklus, dan berdasarkan seluruh pembahasan serta analisis yang telah dilakukan dapat disimpulkan sebagai berikut: (1) Pembelajaran dengan penemuan terbimbing memiliki dampak positif dalam meningkatkan prestasi belajar siswa yang ditandai dengan peningkatan ketuntasan belajar siswa dalam setiap siklus, yaitu siklus I $(65,22 \%)$, siklus II $(78,26 \%)$, siklus III $(91,30 \%)$. (2) Penerapan metode pembelajaran penemuan terbimbing mempunyai pengaruh positif, yaitu dapat meningkatkan motivasi belajar siswa yang ditunjukan dengan rata-rata jawaban siswa yang menyatakan bahwa siswa tertarik dan berminat dengan metode pembelajaran penemuan terbimbing sehingga mereka menjadi termotivasi untuk belajar.

\section{Saran}

Dari hasil penelitian yang diperoleh dari uraian sebelumnya agar proses belajar mengajar IPA lebih efektif dan lebih memberikan hasil yang 
optimal bagi siswa, maka disampaikan saran sebagai berikut: (1) Untuk melaksanakan metode pembelajaran penemuan terbimbing memerlukan persiapan yang cukup matang, sehingga guru harus mempu menentukan atau memilih topik yang benar-benar bisa diterapkan dengan metode pembelajaran penemuan terbimbing dalam proses belajar mengajar sehingga diperoleh hasil yang optimal. (2) Dalam rangka meningkatkan prestasi belajar siswa, guru hendaknya lebih sering melatih siswa dengan berbagai metode pengajaran, walau dalam taraf yang sederhana, dimana siswa nantinya dapat menemukan pengetahuan baru, memperoleh konsep dan keterampilan, sehingga siswa berhasil atau mampu memecahkan masalahmasalah yang dihadapinya. (3) Perlu adanya penelitian yang lebih lanjut, karena hasil penelitian inihanya dilakukan di SDN 2 Seponti tahun pelajaran 2019/2020. (4) Untuk penelitian yang serupa hendaknya dilakukan perbaikan-perbaikan agar diperoleh hasil yang lebih baik.

\section{DAFTAR PUSTAKA}

Arikunto, Suharsimi. 2002. Dasar-dasar Evaluasi Pendidikan. Jakarta: Bumi Aksara.

Arikunto, Suharsimi. 2002. Prosedur Penelitian Suatu Pendekatan Praktek. Jakarta: Rineksa Cipta.

Dahar, R.W. 1989. Teori-teori Belajar. Jakarta: Erlangga.

Departemen Pendidikan dan Kebudayaan, 1994. Petunjuk Pelaksanaan Proses Belajar Mengajar, Jakarta. Balai Pustaka.

Djamarah, Syaiful Bahri. 2000. Strategi Belajar Mengajar. Jakarta: Rineksa Cipta.
Djamarah. Syaiful Bahri. 2002. Psikologi Belajar. Jakarta: Rineksa Cipta.

Hamalik, Oemar. 1994. Media Pendidikan. Bandung: Citra Aditya Bakti.

KBBI. 1996. Edisi Kedua. Jakarta: Balai Pustaka.

Kemmis, S. dan Mc. Taggart, R. 1988. The Action Research Planner. Victoria Dearcin University Press.

Ngalim, Purwanto M. 1990. Psikologi Pendidikan. Bandung: PT. Remaja Rosdakarya.

Nur, Moh. 2001. Pemotivasian Siswa untuk Belajar. Surabaya. University Press. Universitas Negeri Surabaya.

Purwanto, N. 1988. Prinsip-prinsip dan Teknis Evaluasi Pengajaran. Bandung. Remaja Rosda Karya.

Sardiman, A.M. 1996. Interaksi dan Motivasi Belajar Mengajar. Jakarta: Bina Aksara.

Sudjana, N dan Ibrahim. 1989. Penelitian dan Penilaian Pendidikan. Bandung: Sinar Baru.

Sudjana. 1996. Metoda Statistik. Bandung: Tarsito.

Surakhmad, Winarno. 1990. Metode Pengajaran Nasional. Bandung: Jemmars.

Suryosubroto, B. 1997. Proses Belajar Mengajar di Sekolah. Jakarta: PT. Rineksa Cipta.

Suryosubroto. 1997. Proses Belajar Mengajar di Sekolah. Jakarta: PT. Rineksa Cipta.

Syah, Muhibbin. 1995. Psikologi Pendidikan, Suatu Pendekatan Baru. Bandung: Remaja Rosdakarya.

Usman, Moh. Uzer. 2001. Menjadi Guru Profesional. Bandung: Remaja Rosdakarya.

Usman, Uzer. 2000. Menjadi Guru Profesional. Bandung: PT. Remaja Rosdakarya. 